\title{
ISSUES AND PROBLEMS RELATED TO TESTING LANGUAGE SKILLS IN A CROSS-CULTURAL SETTING
}

\author{
${ }^{*}$ C. Walton
}

In this paper I hope to explore some of the issues surrounding the use of tests of language skills in Aboriginal schools. In doing this I hope readers are given a few starting points from which to explore their own answers to the following questions:

1. What is reading?

What do we really believe about the reading process?

What theoretical assumptions underlie our practice?

2. What does our theory tell us about the reading process as experienced by culturally and linguistically different children?

3. What have we learnt so far about teaching reading to Aboriginal children?

4. How have we tried to evaluate Aboriginal children's language skills in the past?

What have we learnt from this?

5. What are the responsibilities of educators when assessing language skills in a cross-cultural setting?

The areas of listening, speaking, reading and writing are obviously interrelated. I want to look particularly at reading. In doing so the importance of the other areas is not being ignored, but what has been learnt about the reading process over the last ten years has implications for the other areas that are becoming more apparent. In terms of current theory and practice the impact of the psycholinguists initially in the reading area is now being felt in the other areas of language. One of the leading psycho-1inguists is Frank Smith. This is what he says about the reading process:

*Ms Christine Walton, Dept. of Education, N.T. 
Reading involves information that the reader receives through his visual system (the marks on the page) and information that he already has available in his head, in cognitive structure...knowledge of language is crucial non-visual information that the reader himself must supply. Similarly, very little reading will take place if the subject matter of the text is completely removed from the experience of the reader.

(Smith, 1975, p.50)

The psychologists speak of the child's use of three cueing systems in his quest for meaning from print: graphophonic, syntactic, semantic.

When we evaluate reading our methodology should tap into the child's use of these three systems. It should enable us to gain information about the child's use of the cueing systems in such a way as to suggest clearly to teachers strategies they may need to develop in teaching that child to use these cueing systems effective1y. To this end Miscue Analysis was developed as a diagnostic tool that tapped into the use made of these cueing systems by individual children.

The work of F. Smith, Ken \& Yetta Goodman, C. Burke, Max Kemp and others has greatly enhanced our knowledge of the reading process. For children to get meaning from print they must bring to the task an understanding of not only the relationships between the marks on the page and sounds in language (grapho-phonics) but also their world knowledge as it relates to what is being read (semantics) and also knowledge of word order (syntax). These three systems enable the child to predict what the next word or group of words is likely to be and to comprehend the passage.

When children are reading a language that is not their mothertongue they are at a disadvantage in each of these three areas, e.g., the different sound systems of English and Aboriginal languages, the possible difference between the world knowledge of the reader and the writer and the possible lack of familiarity with the structure of the English language.

Past approaches to the teaching of reading did not consider these barriers to learning; for example, a traditionally oriented Aboriginal child was expected to learn to read in English using materials designed for language learners, set in urban situations, using stilted, structured and often meaningless text. In the 
Northern Territory we have begun, in two significant ways, to break down these barriers to learning to read:

1. the bilingual program where a child learns to read in his mother tongue before learning to read in English, and

2. the Tracks Language Program that, in combination with a good oral language program, at least introduces children to reading in English by offering reading material that is familiar in content to the experiences of the child. Having become familiar with the structures of the English language, children read books that have some meaning and relate to their own experience of the world. It is an attempt to make initial English language learning meaningful.

I believe that these two innovations represent a vast improvement over previous methodologies. To evaluate the success or otherwise of our endeavours teachers need to be tuned into the reading process as experienced by their students. We may, at some time in the future, assist teachers in this by developing evaluation tools that tap into the reading process as experienced by the students. To date no such instruments exist other than individual diagnostic tools such as Miscue Analysis. If we are to attempt to design tests for our situation we need to clarify their purpose. What do we expect the test to do for us? If tests are to have a function they must be of real value to teachers when they are selecting their educational strategies and developing their programs in relation to individual children or groups of children. The trend in reading research in recent years has been towards individual diagnostic type tests and away from standardised/normative type tests as they offer little help to the teacher. It is generally felt that the older tests, with their emphasis on quantification, do not tap the real skills of the children and do not provide any useful information for the teacher, which is the primary, legitimate function of a test.

As Keogh (1974) puts it when talking about the I.T.P.A. (Illinois Test of Psycholinguistic Abilities):

Such quantification may provide some comfort to the quantifier but does not provide direction in solving the problem. (p. 132)

Australian researchers tend to agree. Dwyer (Queensland Department of Education) was instrumental in spearheading the Queensland Van Leer Program. He states: 
By now enough should have been said about language difference and the influence of teacher expectations on pupil performance to alert us to the need to use great care in our interpretation of language test results achieved by Aboriginal children. (Dwyer, 1976)

It has been the failing of many Australian education programs that test instruments designed for a limited purpose and normed usually on overseas American middle class white samples, have been used in Australia on Aboriginal children. The validity of this use of tests has been questioned repeatedly. If we are to test reading we have to be sure about the validity of the measuring device we choose to use. Tests normed on U.S. samples have been questioned for use even for first language white Australians. To be valid and reliable instruments, normative tests have to be researched extensively to ensure that the purpose of the test is in keeping with our use of it. In some reading $I$ did in $1982 \mathrm{I}$ was surprised to find that tests used in some Australian experimental programs had been normed in the U.S. in the $1950^{\prime} \mathrm{s}$ and that tests normed and designed for children speaking English as a first language were being used with second language speakers even when the manuals for the tests state that this is inappropriate.

e.g., P.P.V.T. (Peabody Picture Vocabulary Test). Dunn (1965) states in the manual -

The scale may be given to any English speaking resident of the U.S. (p.25)

The test itself was standardised in 1958 on a group of white children on1y (Dunn, 1965, p.27).

With reference to using American tests in Australia, Teasdale and de Vries (1976) criticise the fact that -

Scaled scores based directly on the performance of the normative group in the U.S. have been widely used in the analysis of data, generally without any assessment or comment on their applicability to Australian conditions.

They cite a study in Australia that shows that the American norms are "misleading" and "inappropriate". They suggest, if using the test (I.T.P.A.) in Australia - 
1. Use raw score data only.

2. Use it only with children whose mother tongue is English.

3. Do not use American norms.

(Teasdale \& de Vries, 1976, pp.261-2)

There is need to assess skills in the use of English in the Northern Territory but teachers would be better using their own judgement based on performance observed rather than relying on tests quite obviously designed for a different purpose and clientele. include:

Other factors that need to be considered when looking at tests

1. The 1anguage used in the test instructions. Severson and Gest (1970, p.323) cite studies -

that suggest the operation of another test-related factor... understanding of test instructions which may accrue to the detriment of persons whose language is characterised by different structural and dialectal features than that of the examiner.

2. Testing methodologies and situations. In his study, Labov (1973, p.52) shows the different linguistic responses that can be generated by particular testing methodologies and situations, i.e., a Negro boy in a formal setting of a New York school in interaction with a white interviewer, is compared with a boy in a casual, relaxed setting with a black interviewer. The differences in the linguistic behaviour elicited were substantial.

When we look at test results we are looking for insights into language competence. It is difficult to extrapolate from the results on tests if the tests are inappropriate or invalid. It is even harder if, using such tests, we are looking for the causes behind the apparent results. We can hypothesise about a myriad of factors that will range from biased conjecture to informed opinion and still be "off the mark". We can locate the problem as identified by the tests as within the child, the home, the teaching program, or a combination of all of these. But, if the 'problem' is even in part a product of the test construction, we may be chasing a paper tiger. We can, and often have ignored some obvious factors while searching for more elusive construction, e.g., we can use a test designed for first 
language learners on a population of second language learners and decide that they are all 'deprived', suffering 'cognitive deficits', and in need of 'remediation'. Similarly we can compare the students' results with a middle class white sample from America but do we stop to think about the state of health of the respective populations. We can ask - did the norming sample not only not include E.S.L. students and culturally different children, but were the students in the sample experiencing the level of health disorders that we know exists in our students? This may seem of little consequence, but the following figures should make my point:

Middleton and Francis (1976, p.132) examined 73 children on an Aboriginal settlement. Of these 73 children $38.4 \%$ had infected and/or damaged ears. A mild hearing loss can mean that the teacher's normal voice is heard as a whisper. Given a lot of background noise (e.g. rattly air conditioners) the teacher would not be heard or understood at all. If you combine this with a teacher speaking a different language or dialect, you get the idea that the children are doing remarkably well considering all the factors seemingly designed to make learning difficult for them. I don't believe we take the E.S.L. and health status of our students seriously enough either as teachers or as administrators and policy makers. In the United States this issue has been faced in the courts. Lopez (1978, p.4.) states that:

In 1974 the movement for bilingual education produces a landmark decision by the U.S. Supreme Court in the Lau $v$. Nichols case. The court unanimously agreed that there was not equality of treatment merely by providing students with the same facilities, textbooks, teachers and curriculum. For students who do not understand English are effectively foreclosed from any meaningful education.

If we were really to face this issue it would be reflected in such things as staff training, teacher pupil ratios, dollars, etc. We tend to act administratively as if the students were English speaking. The above quote from Lopez can be extended to read that there is not equality of treatment merely by providing the same tests. If test results were to be interpreted as identifying problem areas within our supply of an educational service, and not within the child, it might be administratively justified to use them, given that we are very selective and that we are satisfied as to their validity. It is sadly possible, though, that we may be using quite unsophisticated techniques instead, such as testing children in a second language with out-of-date tools, and then using the results to blame or explain 
away the failure of Aboriginal children in our schools rather than take some responsibility ourselves.

The problems in Aboriginal education are many faceted. Simple solutions are not to be found. Education, after all, is only one small piece of the overall picture. We have to consider what the problems really are. We cannot continue to blame the victims of our neglect. Jenks $(1972$, p.6) gives us this to think about:

If, for example, a nation refuses to send children with red hair to school, the genes that cause red hair can be said to lower reading scores. This does not tell us that children with red hair cannot learn to read. Attributing red heads' illiteracy to their genes would probably strike most teachers as absurd under these circumstances.

If we ignore things like the second language learner and the health status of our students can we then blame them for their poor performance on our tests even if we make sure the tests are o.k.? This is only part of the picture. If we are to evaluate children's progress in reading, for example, can we avoid ethnocentric bias?

Nurcombe (1976, p.185) puts it like this:

Thus blinded by our ethnic spectacles we see Aboriginals in terms of deficit. Only recently have we begun to inquire about the nature of their dialect, their aspirations and their self-image.

Given what we know about tests, the reading process, the cultural background of the students, their linguistic differences, and the warnings of researchers who have made these mistakes before us, and all the other factors that complete the picture, can we honestly and professionally blindly go ahead and administer an inappropriate test and then take its results seriously. We need to find our own answers to the questions posed at the beginning and learn from the experience and mistakes of researchers, teachers, educationists generally who have trod that path before us. We can, given that information, develop our own answers. We need also to trust our own professional judgement.

No test, however cleverly it is constructed, can substitute for the insights professional teachers get from working closely with children. (Goodman, p.33) 


\section{REFERENCES}

Dunn, L.M., 1965: Peabody Picture Vocabulary Test, Manual. A.G.S. Inc., Minnesota, U.S.A.

Dwyer, L.J.: A language program for Aboriginal children. The Exceptional Child, 23,1, March 1976.

Goodman, K.S., (n.d.): Testing in reading: a general critique. In R.R. Rude11, (Ed.):Accountability and Reading Instruction Critical Issues. National Council of Teachers of Education, Urbana, Illinois, pp. 21-33.

Jenks, C., 1972: Inequality. Penguin Books, G.B.

Keogh, B.K., 1974: Psychological evaluation of exceptional children: old hangups and new directions. In R.L. Jones and D. L. MacMillan (Eds): Special Education in Transition. Allyua and Bacon Inc., Boston, U.S.A. pp.131-6.

Labov, W., 1973: The logic of non-standard English. In N. Keddie (Ed.): Tinker, Tailor...The Myth of Cultural Deprivation. Penguin Education, G.B.

Lopez, M., 1978: Bilingual education and the Latino student. In L.A. Valverdo (Ed.), Bilingual Education for Latinos. Assoc. for Supervision and Curriculum Development, Washington D.C.

Middleton, M.R. and Francis, S.H., 1976: Yuendumu and Its Children: Life and Health on an Aboriginal Settlement. Australian Government Publishing Service, Canberra.

Nurcombe, B., 1976: Children of the Dispossessed. A consideration of the Nature of Intelligence, Cultural Disadvantage, Educational Programs for Culturally Different People, and the Development and Expression of Competencies. A Culture Learning Institute Monograph, East-West Center, The University Press of Hawaii.

Severson, R.A. and Gest, K.D., 1970: Towards standardised assessment of the language of disadvantaged children. In F.Williams (Ed.): Language and Poverty: Perspectives on a Theme. Markham Pub. Co., Chicago.

Smith, F., 1975: Comprehension and Learning. A Conceptual Framework for Teachers. Holt, Rinehart and Winston, U.S.A.

Teasdale, G.R. and de Vries, T., 1976: The use of the Illinois Test of Psycholinguistic Abilities with Aboriginal Australian children. In G.E. Kearney and D.W. McElwain (Eds): Aboriginal Cognition: Retrospect and Prospect. Psychology Series No.1, Australian Institute of Aboriginal Studies, Canberra. Humanities Press Inc., New Jersey, U.S.A. 
RECOMMENDED FURTHER READING

Goodman, K.S., (n.d.): Testing in reading: a general critique. In R.R. Rude11, (Ed.): Accountability and Reading Instruction Critical Issues. National Council of Teachers of Education, Urbana, Illinois.

Smith, F., 1973: The politics of ignorance. From The Politics of Reading: Point-Counterpoint. I.R.A. Delaware.

McConnochie, K., 1981: White tests, black children: Aborigines, psychologists and education. In Bill Menary (Ed.): Aborigines and Schooling. Adelaide College of Arts and Education.

Position Papers from the Australian Reading Association.

\section{THE ABORIGINAL CHILD AT SCHOOL A National Journal for Teachers of Aboriginals \\ 5 issues per year}

Annual subscription rates within Australia :

Individua1s, Institutions, Libraries etc. $\ldots \ldots \ldots \ldots \ldots \ldots 10.00$

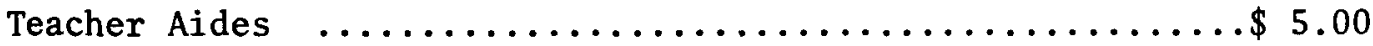

Overseas......\$12.50

(NOTE: Schools with a significant Aboriginal enrolment are entitled to one free copy of each issue. Schools with large Aboriginal enrolments are entitled to 2 free copies of each issue).

Cheques and Money orders payable to -

The Aboriginal Child at School

Aboriginal Education (Munro Street)

University of Queensland, St Lucia 4067 